\title{
Relationships between polyamines, ethylene, osmoprotectants and antioxidant enzymes activities in wheat seedlings after short-term PEG- and NaCl-induced stresses
}

\author{
Maciej Grzesiak • Maria Filek • Anna Barbasz • \\ Barbara Kreczmer · Héliné Hartikainen
}

Received: 31 January 2012/ Accepted: 27 September 2012/Published online: 6 October 2012

(C) The Author(s) 2012. This article is published with open access at Springerlink.com

\begin{abstract}
Contents of ethylene, osmoprotectants, levels and forms of polyamines (PAs) and activities of antioxidant enzymes in the leaves and roots were investigated for five wheat cultivar seedlings (differing in drought tolerance) exposed to osmotic stress $(-1.5 \mathrm{MPa})$. Stress was induced by 2-day-long treatment of plants with polyethylene glycol 6000 (PEG) or $\mathrm{NaCl}$ added to hydroponic cultures. Nawra, Parabola and Manu cv. (drought tolerant) showed a marked increase in osmoprotectors (proline and soluble carbohydrates, mainly glucose, saccharose and maltose), free PAs (putrescine Put, spermidine Spd and spermine Spm) and Spd-conjugated levels, in both leaves and roots, after PEGtreatments. Radunia and Raweta (drought sensitive) exhibited smaller changes in the content of these substances. The analysis of enzymes involved in proline metabolism revealed the glutamate as a precursor of proline synthesis in PEGinduced stress conditions. The increase in the activity of antioxidative enzymes, especially catalase and peroxidases, was characteristic for tolerant wheat plants, but for sensitive ones, a decrease in superoxide dismutase and an increase in mainly glutathione reductase activities were observed. After $\mathrm{NaCl}$-treatment smaller changes of all biochemical parameters were registered in comparison with PEG-induced
\end{abstract}

M. Grzesiak $(\square) \cdot$ M. Filek

Institute of Plant Physiology, Polish Academy of Sciences,

Niezapominajek 21, 30-239 Kraków, Poland

e-mail: m.grzesiak@ifr-pan.krakow.pl

A. Barbasz - B. Kreczmer

Institute of Biology, Pedagogical University,

Podbrzezie 3, 31-054 Kraków, Poland

H. Hartikainen

Department of Food and Environmental Sciences,

University of Helsinki, P.O. Box 27, 00014 Helsinki, Finland stress. Exceptions were the higher values of ethylene content and a significant increase in saccharose, raffinose and maltose levels (only in stress sensitive plants). The proline synthesis pathway was stimulated from both glutamate and ornithine precursors. These results suggest that the accumulation of inorganic ions in $\mathrm{NaCl}$-stressed plants may be involved in protective mechanisms as an additional osmoregultor. Thus, a weaker stressogenic effect as determined as water deficit by leaf relative water content and relative dry weight increase rate and differences in metabolite synthesis in comparison with PEG stress was observed. Proline seems to be the most important osmo-protector in osmotic stress initiated by both PEG and $\mathrm{NaCl}$. The synthesis of sugars and PAs may be stimulated in a stronger stress conditions (PEG).

Keywords Antioxidant enzymes - Carbohydrates · Ethylene · Osmotic stress · Polyamines · Proline · Stress tolerance $\cdot$ Wheat

\section{Introduction}

Water deficit induced by drought and/or salinity is one of the most harmful environmental stresses to which plants are frequently exposed during their life cycle. The limitation in the availability of water caused by drought or soil salinity induces osmotic stress, therefore both stressors can have similar effects on the physiology of plants (Liu et al. 2008). One stress tolerance strategy of plants is to accumulate osmoregulators which act as a substitute of water molecules under condition of water deficit (Valentovic et al. 2006). Due to their high hydrophilicity, the increase in the concentration of organic solutes such as proline, sucrose and other soluble sugars may stabilize the cellular 
osmotic pressure under drought stress, while under salt stress, accumulated ions $\left(\mathrm{Na}^{+}\right.$and $\left.\mathrm{Cl}^{-}\right)$may additionally serve as inorganic osmoregulators (Sucre and Suárez 2011). Moreover, polyamines (PAs), due to their hydrophilicity properties, involvement in the $\mathrm{pH}$ maintaining system of the cell and as active oxygen scavenging compounds are considered as mediators in protective reactions against different stresses (Tiburcio et al. 1997; Kovács et al. 2010).

The general response of various plant species to water stress in relation to PAs synthesis is a change in free PAs levels. In most cases the level of the diamine putrescine (Put) decreased while the triamine spermidine (Spd) and/or the tetramine spermine (Spm) increased (Tang and Newton 2005). However, the fluctuations of PAs levels varied among plant species and depend on the stress duration (Iqbal et al. 2006; Liu et al. 2008). It has been suggested that stress-tolerant plants increased exogenous PAs level to a greater extent than sensitive ones and those with a higher number of amino groups (Spm and Spd) are more effective in scavenging of reactive oxygen species (ROS), produced under stress conditions, than Put (Kubiś 2008). A decrease in titers of individual fractions or total PAs has also been demonstrated, which indicated complex polyamine biosynthesis in response to stress (Goyal and Asthir 2010). It was also proposed that conjugated forms of PAs may be involved in the defense mechanism as controllers of free PAs transport and as regulators of the PAs-titer in stress conditions (Liu et al. 2006). PAs can be covalently conjugated with small molecules such as hydroxycinnamics, forming perchloric acid (PCA) soluble PAs conjugates or they may be covalently bound to macromolecules such as proteins, forming PCA insoluble PAs conjugates (Liu et al. 2004a). There are parallel changes in free and conjugation PAs content during prolonged low temperature treatment of wheat seedlings (vernalization) (Filek et al. 2010). Scaramagli et al. (2000) suggested that insoluble conjugated Put was closely associated with polyethylene glycol induced acclimation of potato cells suspension. Moreover, a significant increase in the insoluble Put conjugates level in leaves of drought tolerant wheat seedlings under osmotic stress was connected with marked increases of free-Spd and Spm levels (Liu et al. 2004a) showing that these PAs facilitated osmotic stress tolerance of wheat seedlings.

The biosynthesis pathway of PAs is linked with that of ethylene via S-adenosylmethionine (SAM) and it has been suggested that there is competition between ethylene and PA production for SAM (Ke et al. 2002). The interaction between ROS, ethylene and PAs in leaves of Glycyrrhiza inflata seedlings was quite diverse at various degrees of damage under root osmotic stress ( $\mathrm{Li}$ and Wang 2004). In the seriously damaged leaves ROS synthesis was modulated by the inhibition of ethylene production and by the reduction in PA content. However, interaction among these species remains debatable ( $\mathrm{Li}$ and Wang 2004). The increasing number of papers on this subject shows the importance of understanding PAs and their interaction with selected biomolecules in explaining the mechanism of plant resistance to stress.

The aim of the paper was to determine the response of sensitive and tolerant wheat genotypes to drought and saline stresses and to investigate differences in the mechanisms involved in the protection against these stresses. The correlations between osmoregulators (PAs-proline, PAs-carbohydrates, proline-carbohydrates) and the main enzymatic antioxidants (SOD-CAT, SOD-peroxidase, SOD-GR) were calculated to evaluate a possible link between non- and enzymatic-protectors and the source of stress.

\section{Materials and methods}

\section{Plant material}

Seeds of four Polish spring wheat genotypes (cv. Nawra and Parabola - selected as stress-tolerant and Radunia and Raweta-selected as stress-sensitive) and one Finnish wheat genotype (cv. Manu) were chosen. Stress tolerance of genotypes was estimated initially at the Institute for Plant Breeding (Radzików, Poland) and then confirmed by previous studies (Filek et al. 2012). Seeds were surface sterilized with $10 \%$ sodium hypochloride solution, washed with sterilized distilled water and germinated for 2 days. Seven uniform seedlings of each genotype were placed in the holes of polystyrene plates ( 7 seedlings $\times 5$ genotypes). These plates were lay down on the surface of polyethylene pots $(39 \mathrm{~cm} \times 28 \mathrm{~cm} \times 14 \mathrm{~cm} ; 11 \mathrm{~L})$ filled with sterile half-strength Hoagland nutrient solution (Nagy and Galiba 1995) at $16 \mathrm{~h}$ photoperiod $\left(17 / 20{ }^{\circ} \mathrm{C}\right.$ night/day) and $800 \mu \mathrm{mol} \mathrm{m} \mathrm{m}^{-2} \mathrm{~s}^{-1}$ light intensity (Filek et al. 2012). The solution was renewed every $48 \mathrm{~h}$ under sterile conditions. After 2 weeks culture when seedlings were at the 3rd-leaf phase, osmotic stress was imposed by application of PEG 6000 (polyethylene glycol, $26 \% \mathrm{w} / \mathrm{v}$ ) or $\mathrm{NaCl}$ $\left(0.4 \mathrm{~mol} \mathrm{dm}^{-3}\right)$ in half-strength Hoagland nutrient solution for 2 days. Osmotic potentials of both PEG and $\mathrm{NaCl}$ solutions were verified with a vapor pressure osmometer (Wescor Inc., Logan, UT, USA) and stabilized to $-1.5 \mathrm{MPa}$. Control seedlings were not exposed to osmotic stress. After 2 days stress, thirty seeds of each wheat genotype per salt and PEG treatment as well as for the control were used for analysis of leaf relative water content (LRWC) and relative dry weight increase rate (RDIR). For biochemical determination, thirty seeds of each genotype per salt and PEG treatment as well as for control in six independent experiments were collected. Biochemical parameters were detected on the 2 nd leaf of all plants and 
in the root system. Samples for enzymatic analysis were stored at $-80{ }^{\circ} \mathrm{C}$.

Determination of leaf relative water content and relative dry weight increase rate

LRWC was calculated according to formula:

$\operatorname{LRWC}(\%)=[(\mathrm{FW}-\mathrm{DW}) /(\mathrm{TW}-\mathrm{DW})] \times 100$

where FW, DW and TW represents the fresh weight, dry weight and saturation weight respectively, using second fully expanded leaf of each seedlings as sample.

RDIR was expressed as:

$\operatorname{RDIR}(\%)=($ GR treatment $/$ GR control $) \times 100$

where GR was calculated from the formula:

$\mathrm{GR}(\%)=[(\mathrm{DW}$ after stress $-\mathrm{DW}$ before stress $) /$ (DW before stress) $] \times 100$

(Liu et al. 2004b).

Proline analysis

Total proline was extracted by the method of Bates et al. (1973). Leaf and root samples (0.1 $\mathrm{g}$ of fresh weight, FW) were homogenized in $10 \mathrm{ml}$ of $3 \%$ aqueous sulfosalicylic acid and centrifuged at $1,000 \times g\left(10 \mathrm{~min}, 4{ }^{\circ} \mathrm{C}\right)$. Two milliliters of the supernatant was mixed with $2 \mathrm{ml}$ of ninhydrin $\left(1 \%\right.$ in $60 \%$ acetic acid) for $1 \mathrm{~h}$ at $100{ }^{\circ} \mathrm{C}$. After cooling to room temperature, the reaction mixture was extracted with $4 \mathrm{ml}$ toluene and vortex shaken. The absorbance of toluene phase was measured at $520 \mathrm{~nm}$ using toluene as a solvent.

Enzyme assay for proline metabolism

Frozen samples (about $5 \mathrm{~g}$ ) were homogenized in $100 \mathrm{mmol} \mathrm{dm}^{-3}$ potassium phosphate (KP) buffer ( $\mathrm{pH}$ 7.4) containing $1 \mathrm{mmol} \mathrm{dm}^{-3}$ ethylenediaminetetraacetic acid (EDTA), $10 \mathrm{mmol} \mathrm{dm}^{-3}$ b-mercaptoethanol, $1 \%$ (w/v) polyvinylpolypyrrolidone (PVPP), $5 \mathrm{mmol} \mathrm{dm}{ }^{-3} \mathrm{MgCl}_{2}$, $0.6 \mathrm{~mol} \mathrm{dm}^{-3} \mathrm{KCl}$ and centrifuged at $13,000 \times g$ for $15 \mathrm{~min}$ at $4{ }^{\circ} \mathrm{C}$ (Lutts et al. 1999).

The activity of D1-pyrroline-5-carboxylate synthase (P5CS; EC 2.7.2.11) was determined according to the method of Stines et al. (1999) in a reaction mixture containing $75 \mathrm{mmol} \mathrm{dm}{ }^{-3}$ L-glutamate, $20 \mathrm{mmol} \mathrm{dm}{ }^{-3} \mathrm{MgCl}_{2}$, $100 \mathrm{mmol} \mathrm{dm}^{-3}$ Tris- $\mathrm{HCl}, 5 \mathrm{mmol} \mathrm{dm}{ }^{-3}$ ATP, $0.4 \mathrm{mmol}$ $\mathrm{dm}^{-3}$ NADPH. The reaction was stared by the addition of $0.5 \mathrm{ml}$ enzymatic extract and after incubation at $37^{\circ} \mathrm{C}$ for $20 \mathrm{~min}$, the absorbance was recorded at $\lambda=340 \mathrm{~nm}$ using spectrophotometer (Biochrom Ultrospec II, LKB, Sweden). D1-pyrroline-5-carboxylated reductase (P5CR; EC 1.5.1.2) activity was measured in the mixture containing 0.06 mmol dm ${ }^{-3} \mathrm{NADH}, 0.15 \mathrm{mmol} \mathrm{dm}{ }^{-3}$ D1-pyrroline-5-carboxylic acid, $120 \mathrm{mmol} \mathrm{dm}^{-3} \mathrm{KP}$ buffer, $2 \mathrm{mmol} \mathrm{dm}^{-3}$ dithiothreitol and enzyme extract and the decrease in the absorbance was followed at $\lambda=340 \mathrm{~nm}$ (Madan et al. 1995). Ornithine-D-aminotransferase (OAT; EC 2.6.1.68) was assayed by the method of Vogel and Kopac (1960). The enzyme extract was added to $100 \mathrm{mmol} \mathrm{dm}{ }^{-3} \mathrm{KP}$ buffer $(\mathrm{pH}$ 8.0 ) in the proportion $0.2: 0.8 \mathrm{ml}$. Buffer contained $50 \mathrm{mmol} \mathrm{dm}^{-3}$ L-ornithine, $20 \mathrm{mmol} \mathrm{dm}^{-3}$ a-ketoglutarate and $1 \mathrm{mmol} \mathrm{dm}^{-3}$ pyridoxal-5' -phosphate. After incubation at $37{ }^{\circ} \mathrm{C}$ for $30 \mathrm{~min}$, the reaction was stopped by adding $0.5 \mathrm{ml} 10 \%$ trichloroacetic acid and then the mixture of $0.5 \% o$-aminobenzaldehyde in ethanol was added. This solution was incubated for $1 \mathrm{~h}$ and centrifuged at 12 $000 \times g$ for $10 \mathrm{~min}\left(4{ }^{\circ} \mathrm{C}\right)$. Absorbance was registered at $\lambda=440 \mathrm{~nm}$. For proline dehydrogenase (PDH; EC 1.5.99.8) detection, the enzyme extract was dissolved in $0.15 \mathrm{~mol} \mathrm{dm}^{-3} \quad \mathrm{Na}_{2} \mathrm{CO}_{3}-\mathrm{HCl}$ buffer (pH 10.3) with $13 \mathrm{mmol} \mathrm{dm}^{-3}$ L-proline and $1.5 \mathrm{mmol} \mathrm{dm}^{-3} \mathrm{NAD}+$ (Lutts et al. 1999) and absorbance was measured at $\lambda=340 \mathrm{~nm}$. All enzymes were expressed as unit per $\mathrm{mg}$ protein. Protein concentration was detected according to the method of Bradford (1976) using bovine serum as a standard.

\section{Soluble carbohydrate measurements}

Carbohydrates were analyzed according to Van $\mathrm{Hu}-$ ylenbroeck and Debergh (1996). Leaf and root samples (100 mg FW) were extracted with $1 \mathrm{ml} 80 \%$ aqueous ethanol containing melezitose as the internal standard (Sigma, USA) and then heated at $90{ }^{\circ} \mathrm{C}$ for $30 \mathrm{~min}$. After $15 \mathrm{~min}$ centrifugation at $3,000 \times g\left(4{ }^{\circ} \mathrm{C}\right)$ the supernatant was evaporated to dryness and dissolved in $2 \mathrm{ml}$ distilled water. The water solution was passed through a Sep Pak Accell QMA cartridge column previously equilibrated with $0.1 \mathrm{~mol} \mathrm{dm}^{-3}$ $\mathrm{NaOH}$, and a Sep Pak plus $\mathrm{C} 18$ cartridge column. The sugar content was analyzed by HPLC (Beckman Instruments, Fullerton, CA, USA) liquid chromatograph using a Shodex SC1011 column at $80{ }^{\circ} \mathrm{C}$. Samples were eluted with $0.1 \mathrm{~mol} \mathrm{dm}{ }^{-3} \mathrm{NaOH}$ at a flow rate of $1.2 \mathrm{ml} \mathrm{min}^{-1}$ and detected by pulse amperometric (ESA Coulochem II) detector with palladium electrodes (potential of oxidation: $+700 \mathrm{mV}$, potential of reduction: $-900 \mathrm{mV}$, potential of analyze: $+200 \mathrm{mV}$ ). Glucose, fructose, sucrose, maltose and raffinose were identified by their retention times and quantified by integrating peak areas versus the internal standard.

Extraction and measurement of free and conjugated polyamines

Free and conjugated PAs were extracted and measured as described earlier (Filek et al. 2010) with minor change. For 
extraction of free PAs approximately $500 \mathrm{mg}$ FW samples (both leaves and roots) were incubated in $2 \mathrm{ml} 10 \%$ PCA for $30 \mathrm{~min}$ at $4{ }^{\circ} \mathrm{C}$. After $20 \mathrm{~min}$ centrifugation at $23,000 \times g\left(4^{\circ} \mathrm{C}\right)$ the supernatant was transferred to a new tube. One milliliter of $10 \%$ PCA was added to the resultant pellet and kept on ice for $30 \mathrm{~min}$ before centrifugation. Then the supernatants from the two centrifugations were combined.

For determination of free and conjugated PA levels, $250 \mu \mathrm{l}$ of the supernatant was hydrolyzed with $12 \mathrm{~mol} \mathrm{dm}{ }^{-3} \mathrm{HCl}$ and heated at $110{ }^{\circ} \mathrm{C}$ for $18 \mathrm{~h}$. After acidic hydrolysis the supernatant was evaporated and the residue was resuspended in $200 \mu 110 \%$ PCA and used for benzoylation reaction according to method of Slocum et al. (1989) and Cvikrová et al. (1999) with 1,7-diaminoheptane (Sigma Algrich, USA) as an internal standard. Polyamine standards (Put, Spd and Spm; Sigma, USA) were prepared similarly to plant samples. All samples were filtered and stored at $-20{ }^{\circ} \mathrm{C}$ for HPLC analysis.

The resulting benzoyl-amines were analyzed by HPLC using Beckman-Video (Beckman Instruments, Fullerton, CA, USA) liquid chromatograph equipped with a UV detector (monitoring the eluate at $254 \mathrm{~nm}$ ). Samples $(10 \mu \mathrm{l})$ were introduced into a $20 \mu \mathrm{l}$ loop and chromatographed at $25^{\circ} \mathrm{C}$ through $\mathrm{C} 18$ Spherisorb 5 ODS2 column (particle size $3 \mu \mathrm{m}$, column dimensions $250 \times 4.6 \mathrm{~mm}$ ). Benzoyl derivatives were eluted at a flow rate of $0.5 \mathrm{ml} \mathrm{min}{ }^{-1}$ using water (solvent A)/methanol (solvent B) gradient: $60 \% \mathrm{~B}$ in 0-1 min, $60-95 \%$ B in $1-13 \mathrm{~min}, 95 \% \mathrm{~B}$ in $13-18 \mathrm{~min}$, 95-60\% in 18-20 min. Conjugated polyamine contents were calculated by subtracting the free polyamine content from the acid-soluble polyamine contents.

\section{Ethylene analysis}

Plant material (500 mg FW) closed in pots $(3 \mathrm{ml})$ was used for determination of ethylene production. After $30 \mathrm{~min}$ $\left(20{ }^{\circ} \mathrm{C}\right.$, natural light conditions), $100 \mathrm{ml}$ air was taken through the septa and shaken with $0.25 \mathrm{~mol} \mathrm{dm}^{-3}$ mercuric perchlorate in $2 \mathrm{~mol} \mathrm{dm}^{-3}$ PCA for 5 min according to Mól et al. (2004). The released ethylene was determined by gas chromatography (Hewlett Packard, 5890) on an RTX-5 Q-PLOT column $(30 \mathrm{~m}$ length $\times 0.53 \mathrm{~mm}$ inner diameter, RESREC Corp., USA) using flame ionization detector. Column temperature was $60^{\circ} \mathrm{C}$ and injector and detector temperature were 80 and $120^{\circ} \mathrm{C}$, respectively; carrier gas flow

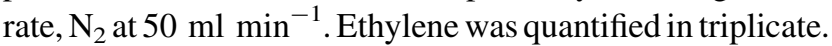

Enzymes extraction and assays

Approximately $150 \mathrm{mg} \mathrm{FW}$ of samples were homogenized in $1.5 \mathrm{ml}$ of a $0.1 \mathrm{~mol} \mathrm{dm}^{-3} \mathrm{KP}$ buffer ( $\mathrm{pH} \mathrm{7.8)} \mathrm{containing}$

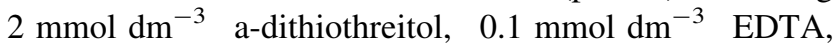

$1.25 \mathrm{mmol} \mathrm{dm}^{-3}$ polyethylene glycol. The mixture was centrifuged at $14,000 \times g$ for $30 \mathrm{~min}$ at $4{ }^{\circ} \mathrm{C}$ and the supernatant was desalted on a PD 10 column (Amersham Biosciences, Sweden).

The activity of SOD (EC 1.15.11) was determined spectrophotometrically (Biochrom Ultrospec II, LKB, Sweden) at $\lambda=595 \mathrm{~nm}$ by the modified method of McCord and Fridovich (1969). One unit of SOD activity was defined as the amount of enzyme necessary for $50 \%$ inhibition of cytochrome $\mathrm{c}$ in a coupled system with xanthine and xanthine oxidase. CAT (EC 1.11.16) activity was measured at $\lambda=240 \mathrm{~nm}$ by the modified method of Aebi (1984) after initiation with a mixture of $0.03 \mathrm{mmol} \mathrm{dm}^{-3}$ solution of $\mathrm{H}_{2} \mathrm{O}_{2}$ in $\mathrm{KP}$ buffer. The activity of POD was detected by the modified method of Lück (1965) by measuring the amount of the products of $1 \% p$-phenylenediamine reaction in the presence of $0.03 \mathrm{mmol} \mathrm{dm}^{-3} \mathrm{H}_{2} \mathrm{O}_{2}$ in KP buffer at $\lambda=$ $485 \mathrm{~nm}$. GR (EC 1.6.4.2) activity was determined as described by Foyer and Halliwell (1976). The assay mixture contained $0.5 \mathrm{mmol} \mathrm{dm}^{-3} \mathrm{NADPH}, 10 \mathrm{mmol} \mathrm{dm}^{-3}$ oxidized glutathione and $3 \mathrm{mmol} \mathrm{dm}{ }^{-3} \mathrm{MgCl}_{2}$ in 0.1 mol dm ${ }^{-3}$ potassium buffer and $0.1 \mathrm{ml}$ of enzyme extract. GR activity was recorded at $\lambda=340 \mathrm{~nm}$. For all enzymes the reaction progress was examined after 60 and $120 \mathrm{~s}$ since the initiation of the reaction. KINLAB software for kinetic determination was used. Enzymes activity was expressed in the relation to protein content in the supernatant.

\section{Statistical analysis}

Data were expressed as mean \pm SE. The statistical analysis was performed by Duncan's multiple range test, taking $p<0.05$ using PC SAS 8.0. The significance between the means was assessed using the SAS ANOVA procedure. The correlation coefficient $(r)$ significant at $5 \%$ level $(p<0.05)$ was calculated between proline and other potential osmoregulators (carbohydrate and PAs) accumulation and between SOD and various anioxidative enzymes under PEG and $\mathrm{NaCl}$ stresses.

\section{Results}

PEG osmotic stress applied for 2 days caused a decrease of LRWC and RDIR in the seedlings of all wheat cultivars, but in Radunia and Raweta (drought sensitive) these parameters diminished more markedly than that of Nawra and Parabola (drought tolerant) (Fig. 1a, b). In Manu (Finnish wheat) the values of LRWC and RDIR were intermediate between that characteristic for drought sensitive and tolerant Polish genotypes.

An increase in accumulation of proline in both leaves and roots of wheat seedlings induced by osmotic stress was 
markedly higher under PEG-treatment than $\mathrm{NaCl}$-application (Tables 1,2). Changes in proline concentrations in leaves of plants selected as less tolerant (Raweta and Radunia) were smaller in comparison to plants selected as more tolerant (Nawra, Parabola) and more significant than that observed in the root. In leaves and roots of Finnish wheat genotype (Manu), an increase in proline accumulation in leaves and roots was similar to those for the tolerant Polish wheat genotypes.

Osmotic stress caused a significant increase in P5CS activity in both leaves and roots of all genotypes in comparison to the control (Fig. 2a, b). After PEG-treatment, P5CS activity increased about threefold and twofold respectively, in tolerant and sensitive plants. After $\mathrm{NaCl}-$ treatment, the rise in activity of this enzyme was smaller (twofold and 0.4-fold respectively) in tolerant and sensitive wheat genotypes. The activity of P5CR also increased about 25 and $10 \%$, respectively under PEG and $\mathrm{NaCl}$ conditions in all investigated plants (Fig. 2c, d). In contrast to $\mathrm{P} 5 \mathrm{CS}$ and P5CR, OAT activity remained unchanged after PEG-treatment and increased about $20 \%$ in NaClstressed plants, being similar in leaves and roots and tolerant and sensitive genotypes (Fig. 2e, f). Both PEG and $\mathrm{NaCl}$ treatment resulted in a decrease in PDH activity, however this drop was smaller in tolerant genotypes after
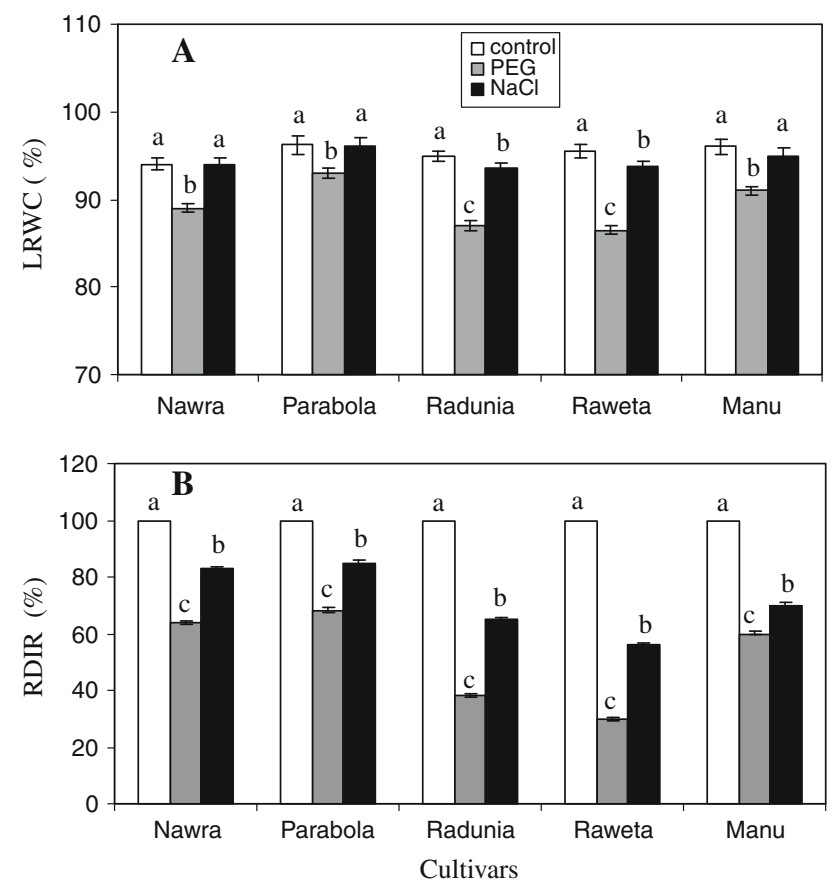

Fig. 1 Effects of PEG and $\mathrm{NaCl}$ on LRWC (leaf relative water content a) and RDIR (relative dry weight increase rate b). Five wheat varieties were treated with polyethylene glycol (PEG 6000, $\Psi=$ $-1.5 \mathrm{MPa})$ and $\mathrm{NaCl}(\Psi=-1.5 \mathrm{MPa})$ for 2 days in hydroponic Hoagland (1:1 with water) media. Values are mean $\pm \operatorname{SE}(n=30)$. Different letters indicate significant $(p<0.05)$ differences between treatments
PEG and in the sensitive cultivars, after $\mathrm{NaCl}$ application to the growth media (Fig. 2g, h).

Glucose and fructose were the main soluble mono-saccharides in both the leaves and roots of the wheat seedlings (Tables 1, 2). Of the di-saccharides, the highest concentrations were for maltose. Generally, higher level of all sugars was found in leaves than in the roots. However both stress factors ( $\mathrm{PEG}$ and $\mathrm{NaCl}$ ) stimulated similar changes of these compounds in comparison to the control. PEGtreatment caused a significant rise of glucose and fructose levels in Nawra, Parabola and Manu cultivars (about twofold to threefold, depending on genotype) but in Radunia and Raweta, only a small rise of fructose (about $10 \%$ ) and a decrease in glucose content was observed as compared to the control. Accumulation of saccharose and maltose increased in all investigated plants with the highest changes measured in the saccharose level (even of about tenfold for Nawra and Parabola and Manu). However, raffinose content decreased in PEG-stressed wheat genotypes. In $\mathrm{NaCl}$-treated plants, the levels of mono-saccharides were changed to a smaller degree and only in Radunia and Raweta genotypes was at twofold drop of fructose content measured as compared to control. Among di-saccharides, saccharose and raffinose content increased in all cultivars but maltose level increased only in Raweta and Radunia.

Put, Spd and Spm were the major free PAs species in leaves and roots of wheat seedlings with Put being the most abundant (Fig. 3). Osmotic stress significantly affected the PA content in the plants. PAs especially of Put and Spm in leaves (Fig. 3a, e), increased after PEG-treatment whereas after NaCl-treatment, PAs slightly decreased (except Spd in roots of Raweta and Radunia genotypes where Spd content significantly increased; Fig. 3d). The ratio of Put/ $(\mathrm{Spd}+\mathrm{Spm})$ was higher for the root system than in the leaves for all wheat genotypes (Fig. 3g, h). For control samples, smaller values of this ratio in the leaves were obtained for Radunia and Raweta. In contrast, lower Put/ $(\mathrm{Spd}+\mathrm{Spm})$ ratios in the roots were characteristic for Nawra, Parabola and Manu. Both types of osmotic stresses induced similar changes in the PAs ratio in leaves of all investigated plants, however, an increase of this parameter was higher in Radunia and Raweta (about threefold for PEG and 1.5-fold for $\mathrm{NaCl}$ ) than for other genotypes (about twofold for PEG and 1.3-fold for $\mathrm{NaCl}$ ). In roots, PEGtreatment resulted in an increase of the PAs ratio in Nawra, Parabola and Manu plants (about 1.3-fold to 1.4-fold) while $\mathrm{NaCl}$-treatment did not stimulate any changes of this parameter. In Radunia and Raweta, PEG-treatment did not influence $\mathrm{PAs}$ ratio, but $\mathrm{NaCl}$-stress decreased this parameter by factor (at about 1/3-1/4 as compare to control; Fig. 3g, h).

Among conjugated PAs only insoluble derivatives of Put and Spd were detected at significant levels in the investigated cultivars (Table 3). PEG application induced 
Table 1 Proline and soluble carbohydrate concentrations in the wheat seedling leaves of 5 varieties after a culture on Hoagland (1:1 with water) media (control) and on the media supplemented with polyethylene glycol (PEG 6000, $\Psi=-1.5 \mathrm{MPa})$ and $\mathrm{NaCl}(\Psi=-1.5 \mathrm{MPa})$

\begin{tabular}{|c|c|c|c|c|c|c|c|}
\hline \multirow[t]{2}{*}{ Object } & \multirow[t]{2}{*}{ Treatment } & \multirow[t]{2}{*}{ Proline $(\mu \mathrm{mol} / \mathrm{g} \mathrm{FW})$} & \multicolumn{5}{|c|}{ Carbohydrates $(\mu \mathrm{g} / \mathrm{mg} \mathrm{FW})$} \\
\hline & & & Glucose & Fructose & Saccharose & Raffinose & Maltose \\
\hline \multirow[t]{3}{*}{ Nawra } & Control & $4.99 \pm 0.07^{\mathrm{c}}$ & $1.001 \pm 0.028^{\mathrm{b}}$ & $0.802 \pm 0.046^{\mathrm{b}}$ & $0.089 \pm 0.005^{\mathrm{c}}$ & $0.033 \pm 0.006^{\mathrm{b}}$ & $0.894 \pm 0.007^{b}$ \\
\hline & PEG & $13.41 \pm 0.12^{\mathrm{a}}$ & $2.505 \pm 0.019^{\mathrm{a}}$ & $1.701 \pm 0.021^{\mathrm{a}}$ & $0.199 \pm 0.017^{\mathrm{a}}$ & $0.008 \pm 0.009^{c}$ & $1.080 \pm 0.008^{\mathrm{a}}$ \\
\hline & $\mathrm{NaCl}$ & $9.20 \pm 0.10^{\mathrm{b}}$ & $1.039 \pm 0.099^{\mathrm{b}}$ & $0.698 \pm 0.044^{\mathrm{b}}$ & $0.151 \pm 0.021^{\mathrm{b}}$ & $0.097 \pm 0.008^{\mathrm{a}}$ & $0.586 \pm 0.022^{\mathrm{c}}$ \\
\hline \multirow[t]{3}{*}{ Parabola } & Control & $5.03 \pm 0.09^{c}$ & $1.174 \pm 0.123^{\mathrm{b}}$ & $0.911 \pm 0.087^{\mathrm{b}}$ & $0.098 \pm 0.032^{\mathrm{c}}$ & $0.062 \pm 0.004^{\mathrm{b}}$ & $0.534 \pm 0.015^{\mathrm{b}}$ \\
\hline & PEG & $14.12 \pm 0.14^{\mathrm{a}}$ & $2.977 \pm 0.512^{\mathrm{a}}$ & $3.269 \pm 0.955^{\mathrm{a}}$ & $0.376 \pm 0.076^{\mathrm{a}}$ & $0.028 \pm 0.002^{\mathrm{c}}$ & $1.009 \pm 0.006^{\mathrm{a}}$ \\
\hline & $\mathrm{NaCl}$ & $10.00 \pm 0.08^{\mathrm{b}}$ & $1.293 \pm 0.032^{\mathrm{b}}$ & $0.934 \pm 0.311^{\mathrm{b}}$ & $0.195 \pm 0.098^{\mathrm{b}}$ & $0.092 \pm 0.003^{\mathrm{a}}$ & $0.397 \pm 0.047^{\mathrm{c}}$ \\
\hline \multirow[t]{3}{*}{ Radunia } & Control & $7.34 \pm 0.10^{\mathrm{c}}$ & $0.969 \pm 0.066^{\mathrm{a}}$ & $0.812 \pm 0.048^{\mathrm{b}}$ & $0.066 \pm 0.012^{\mathrm{b}}$ & $0.024 \pm 0.005^{\mathrm{b}}$ & $0.676 \pm 0.019^{\mathrm{a}}$ \\
\hline & PEG & $10.20 \pm 0.11^{\mathrm{a}}$ & $0.985 \pm 0.098^{\mathrm{a}}$ & $0.994 \pm 0.017^{\mathrm{a}}$ & $0.298 \pm 0.039^{\mathrm{a}}$ & $0.009 \pm 0.006^{\mathrm{c}}$ & $0.621 \pm 0.028^{\mathrm{a}}$ \\
\hline & $\mathrm{NaCl}$ & $8.87 \pm 0.13^{\mathrm{b}}$ & $1.096 \pm 0.024^{\mathrm{a}}$ & $0.832 \pm 0.024^{\mathrm{b}}$ & $0.366 \pm 0.015^{\mathrm{a}}$ & $0.058 \pm 0.009^{\mathrm{a}}$ & $0.342 \pm 0.020^{\mathrm{b}}$ \\
\hline \multirow[t]{3}{*}{ Raweta } & Control & $7.25 \pm 0.06^{\mathrm{c}}$ & $0.874 \pm 0.055^{\mathrm{a}}$ & $0.883 \pm 0.079^{\mathrm{a}}$ & $0.072 \pm 0.009^{\mathrm{b}}$ & $0.027 \pm 0.010^{\mathrm{b}}$ & $0.575 \pm 0.021^{\mathrm{a}}$ \\
\hline & PEG & $9.96 \pm 0.10^{\mathrm{a}}$ & $0.865 \pm 0.043^{\mathrm{a}}$ & $1.016 \pm 0.086^{\mathrm{b}}$ & $0.208 \pm 0.006^{\mathrm{a}}$ & $0.011 \pm 0.007^{\mathrm{c}}$ & $0.533 \pm 0.012^{\mathrm{a}}$ \\
\hline & $\mathrm{NaCl}$ & $8.88 \pm 0.10^{\mathrm{b}}$ & $0.923 \pm 0.041^{\mathrm{a}}$ & $0.913 \pm 0.092^{\mathrm{a}}$ & $0.299 \pm 0.107^{\mathrm{a}}$ & $0.040 \pm 0.002^{\mathrm{a}}$ & $0.386 \pm 0.038^{b}$ \\
\hline \multirow[t]{3}{*}{ Manu } & Control & $4.63 \pm 0.08^{\mathrm{c}}$ & $0.602 \pm 0.017^{b}$ & $0.719 \pm 0.063^{\mathrm{b}}$ & $0.079 \pm 0.022^{\mathrm{c}}$ & $0.035 \pm 0.011^{\mathrm{b}}$ & $0.532 \pm 0.009^{b}$ \\
\hline & PEG & $12.51 \pm 0.11^{\mathrm{a}}$ & $1.546 \pm 0.023^{\mathrm{a}}$ & $1.295 \pm 0.075^{\mathrm{a}}$ & $0.244 \pm 0.031^{\mathrm{a}}$ & $0.011 \pm 0.008^{\mathrm{c}}$ & $0.998 \pm 0.013^{\mathrm{a}}$ \\
\hline & $\mathrm{NaCl}$ & $9.02 \pm 0.12^{\mathrm{b}}$ & $0.610 \pm 0.050^{\mathrm{b}}$ & $0.787 \pm 0.063^{\mathrm{b}}$ & $0.184 \pm 0.044^{\mathrm{b}}$ & $0.090 \pm 0.009^{\mathrm{a}}$ & $0.255 \pm 0.014^{\mathrm{c}}$ \\
\hline
\end{tabular}

Values are mean $\pm \operatorname{SE}(n=6)$. Different letters indicate significant $(p<0.05)$ differences between treatments

Table 2 Proline and soluble carbohydrate concentrations in the wheat seedling roots of 5 varieties after a culture on Hoagland (1:1 with water) media (control) and on the media supplemented with polyethylene glycol (PEG 6000, $\Psi=-1.5 \mathrm{MPa})$ and $\mathrm{NaCl}(\Psi=-1.5 \mathrm{MPa})$ for 2 days

\begin{tabular}{|c|c|c|c|c|c|c|c|}
\hline \multirow[t]{2}{*}{ Object } & \multirow[t]{2}{*}{ Treatment } & \multirow[t]{2}{*}{ Proline $(\mu \mathrm{mol} / \mathrm{g} \mathrm{FW})$} & \multicolumn{5}{|c|}{ Carbohydrates $(\mu \mathrm{g} / \mathrm{mg} \mathrm{FW})$} \\
\hline & & & Glucose & Fructose & Saccharose & Raffinose & Maltose \\
\hline \multirow[t]{3}{*}{ Nawra } & Control & $4.03 \pm 0.07^{\mathrm{c}}$ & $0.785 \pm 0.036^{\mathrm{b}}$ & $0.683 \pm 0.037^{\mathrm{b}}$ & $0.059 \pm 0.010^{\mathrm{c}}$ & $0.022 \pm 0.001^{\mathrm{b}}$ & $0.107 \pm 0.009^{b}$ \\
\hline & PEG & $11.78 \pm 0.14^{\mathrm{a}}$ & $2.107 \pm 0.055^{\mathrm{a}}$ & $1.675 \pm 0.088^{\mathrm{a}}$ & $0.460 \pm 0.019^{\mathrm{a}}$ & $0.001 \pm 0.001^{\mathrm{c}}$ & $0.244 \pm 0.013^{\mathrm{a}}$ \\
\hline & $\mathrm{NaCl}$ & $8.42 \pm 0.09^{\mathrm{b}}$ & $0.804 \pm 0.031^{\mathrm{b}}$ & $0.539 \pm 0.042^{\mathrm{b}}$ & $0.202 \pm 0.011^{\mathrm{b}}$ & $0.033 \pm 0.002^{\mathrm{a}}$ & $0.079 \pm 0.005^{\mathrm{c}}$ \\
\hline \multirow[t]{3}{*}{ Parabola } & Control & $4.18 \pm 0.11^{\mathrm{c}}$ & $0.851 \pm 0.022^{\mathrm{b}}$ & $0.686 \pm 0.011^{\mathrm{b}}$ & $0.054 \pm 0.009^{\mathrm{c}}$ & $0.028 \pm 0.001^{\mathrm{b}}$ & $0.166 \pm 0.007^{\mathrm{b}}$ \\
\hline & PEG & $12.15 \pm 0.16^{\mathrm{a}}$ & $3.812 \pm 0.090^{\mathrm{a}}$ & $3.536 \pm 0.046^{\mathrm{a}}$ & $0.574 \pm 0.057^{\mathrm{a}}$ & $0.013 \pm 0.002^{\mathrm{c}}$ & $0.377 \pm 0.024^{\mathrm{a}}$ \\
\hline & $\mathrm{NaCl}$ & $9.54 \pm 0.10^{\mathrm{b}}$ & $0.904 \pm 0.044^{\mathrm{b}}$ & $0.699 \pm 0.028^{\mathrm{b}}$ & $0.166 \pm 0.038^{\mathrm{b}}$ & $0.031 \pm 0.003^{\mathrm{a}}$ & $0.103 \pm 0.012^{\mathrm{c}}$ \\
\hline \multirow[t]{3}{*}{ Radunia } & Control & $5.57 \pm 0.02^{\mathrm{c}}$ & $0.767 \pm 0.036^{\mathrm{a}}$ & $0.723 \pm 0.031^{\mathrm{b}}$ & $0.053 \pm 0.004^{\mathrm{b}}$ & $0.009 \pm 0.002^{\mathrm{b}}$ & $0.174 \pm 0.009^{\mathrm{a}}$ \\
\hline & PEG & $9.06 \pm 0.11^{\mathrm{a}}$ & $0.790 \pm 0.042^{\mathrm{a}}$ & $0.986 \pm 0.024^{\mathrm{a}}$ & $0.321 \pm 0.036^{\mathrm{a}}$ & $0.001 \pm 0.001^{\mathrm{c}}$ & $0.173 \pm 0.016^{\mathrm{a}}$ \\
\hline & $\mathrm{NaCl}$ & $7.99 \pm 0.08^{\mathrm{b}}$ & $0.906 \pm 0.041^{\mathrm{a}}$ & $0.636 \pm 0.047^{\mathrm{b}}$ & $0.276 \pm 0.022^{\mathrm{a}}$ & $0.027 \pm 0.005^{\mathrm{a}}$ & $0.082 \pm 0.013^{\mathrm{b}}$ \\
\hline \multirow[t]{3}{*}{ Raweta } & Control & $5.21 \pm 0.05^{\mathrm{c}}$ & $0.854 \pm 0.028^{\mathrm{a}}$ & $0.749 \pm 0.036^{\mathrm{b}}$ & $0.098 \pm 0.011^{\mathrm{b}}$ & $0.011 \pm 0.002^{\mathrm{b}}$ & $0.170 \pm 0.022^{\mathrm{a}}$ \\
\hline & PEG & $8.32 \pm 0.09^{\mathrm{a}}$ & $0.699 \pm 0.016^{\mathrm{a}}$ & $0.914 \pm 0.025^{\mathrm{a}}$ & $0.324 \pm 0.016^{\mathrm{a}}$ & $0.001 \pm 0.001^{\mathrm{c}}$ & $0.165 \pm 0.029^{\mathrm{a}}$ \\
\hline & $\mathrm{NaCl}$ & $6.89 \pm 0.04^{\mathrm{b}}$ & $0.726 \pm 0.035^{\mathrm{a}}$ & $0.688 \pm 0.049^{b}$ & $0.316 \pm 0.021^{\mathrm{a}}$ & $0.018 \pm 0.002^{\mathrm{a}}$ & $0.083 \pm 0.014^{b}$ \\
\hline \multirow[t]{3}{*}{ Manu } & Control & $3.86 \pm 0.02^{\mathrm{c}}$ & $0.497 \pm 0.029^{b}$ & $0.401 \pm 0.032^{\mathrm{b}}$ & $0.043 \pm 0.005^{\mathrm{c}}$ & $0.010 \pm 0.001^{\mathrm{b}}$ & $0.148 \pm 0.011^{b}$ \\
\hline & PEG & $10.98 \pm 0.12^{\mathrm{a}}$ & $1.121 \pm 0.048^{\mathrm{a}}$ & $1.044 \pm 0.044^{\mathrm{a}}$ & $0.273 \pm 0.008^{\mathrm{a}}$ & $0.009 \pm 0.001^{\mathrm{c}}$ & $0.350 \pm 0.010^{\mathrm{a}}$ \\
\hline & $\mathrm{NaCl}$ & $7.77 \pm 0.06^{\mathrm{b}}$ & $0.609 \pm 0.047^{\mathrm{b}}$ & $0.367 \pm 0.036^{\mathrm{b}}$ & $0.207 \pm 0.010^{\mathrm{b}}$ & $0.022 \pm 0.001^{\mathrm{a}}$ & $0.075 \pm 0.054^{\mathrm{c}}$ \\
\hline
\end{tabular}

Values are mean $\pm \operatorname{SE}(n=6)$. Different letters indicate significant $(p<0.05)$ differences between treatments

an increase of Spd-conjugates only in Nawra, Parabola and Manu genotypes of about $1 / 3$ in comparison to control. In other cultivars, a decrease of these PAs conjugates concentrations was detected after both PEG and NaCl-treatments. The level of Put conjugates dropped after application of both osmotic stresses, especially in Radunia,
Raweta and Manu plants, where only traces of these PAs derivatives were measured.

Antioxidant enzymes activities, calculated relative to protein content, were generally higher in leaves than in roots (Fig. 4). In PEG-stressed plants, SOD activity decreased in leaves (except in Nawra and Parabola; 

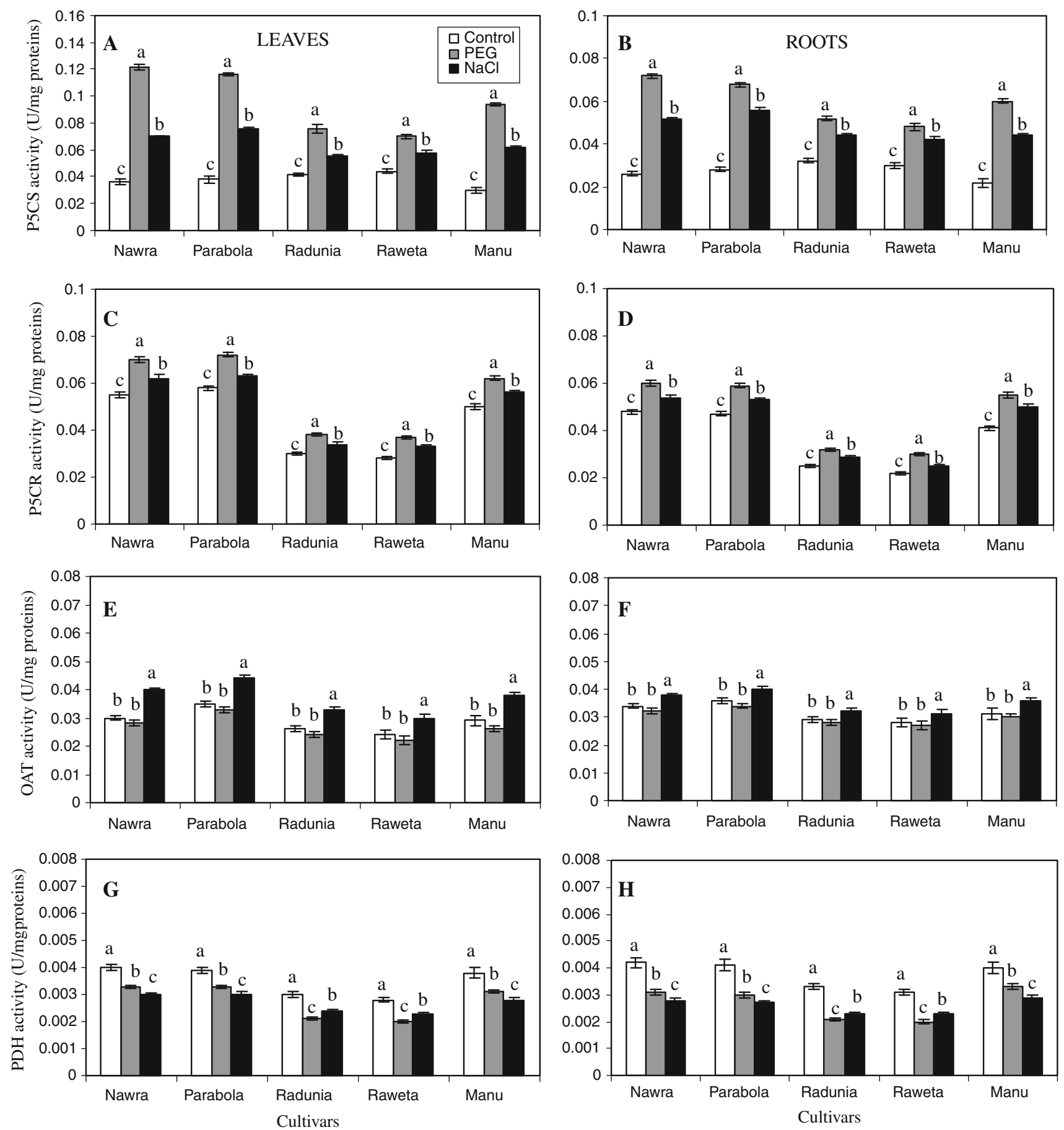

Fig. 2 Activities of $\Delta^{1}$-pyrrolline-5-carboxylate synthetase (P5CS), $\Delta^{1}$-pyrrolline-5-carboxylate reductase (P5CR), ornithine- $\delta$-aminotransferase (OAT) and proline dehydrogenase (PDH) levels in the leaves $(\mathbf{a}, \mathbf{c}, \mathbf{e}, \mathbf{g})$ and roots $(\mathbf{b}, \mathbf{d}, \mathbf{f}, \mathbf{h})$ of 5 wheat varieties after culture on Hoagland (1:1 with water) media (control) and on the

media supplemented with polyethylene glycol (PEG 6000, $\Psi=$ $-1.5 \mathrm{MPa})$ and $\mathrm{NaCl}(\Psi=-1.5 \mathrm{MPa})$ for 2 days. Values are mean $\pm \operatorname{SE}(n=6)$. Different letters indicate significant $(p<0.05)$ differences between treatments

Fig. 4a). This drop was especially visible in Radunia and Raweta (about twofold). In roots, a decrease of SOD activity was measured only in Radunia and Raweta (at about 1/4) as compared to the control (Fig. 4b). After $\mathrm{NaCl}$-treatment, the activity of SOD in the leaves was not changed but increased in roots, especially in Radunia and Raweta (by $30 \%$ relative to the control). POD activity increased in leaves (Fig. 4c) and decreased in roots (Fig. 4d) in PEG-stressed plants. This rise was higher in Nawra and Parabola (more than 2 times as compared to the 

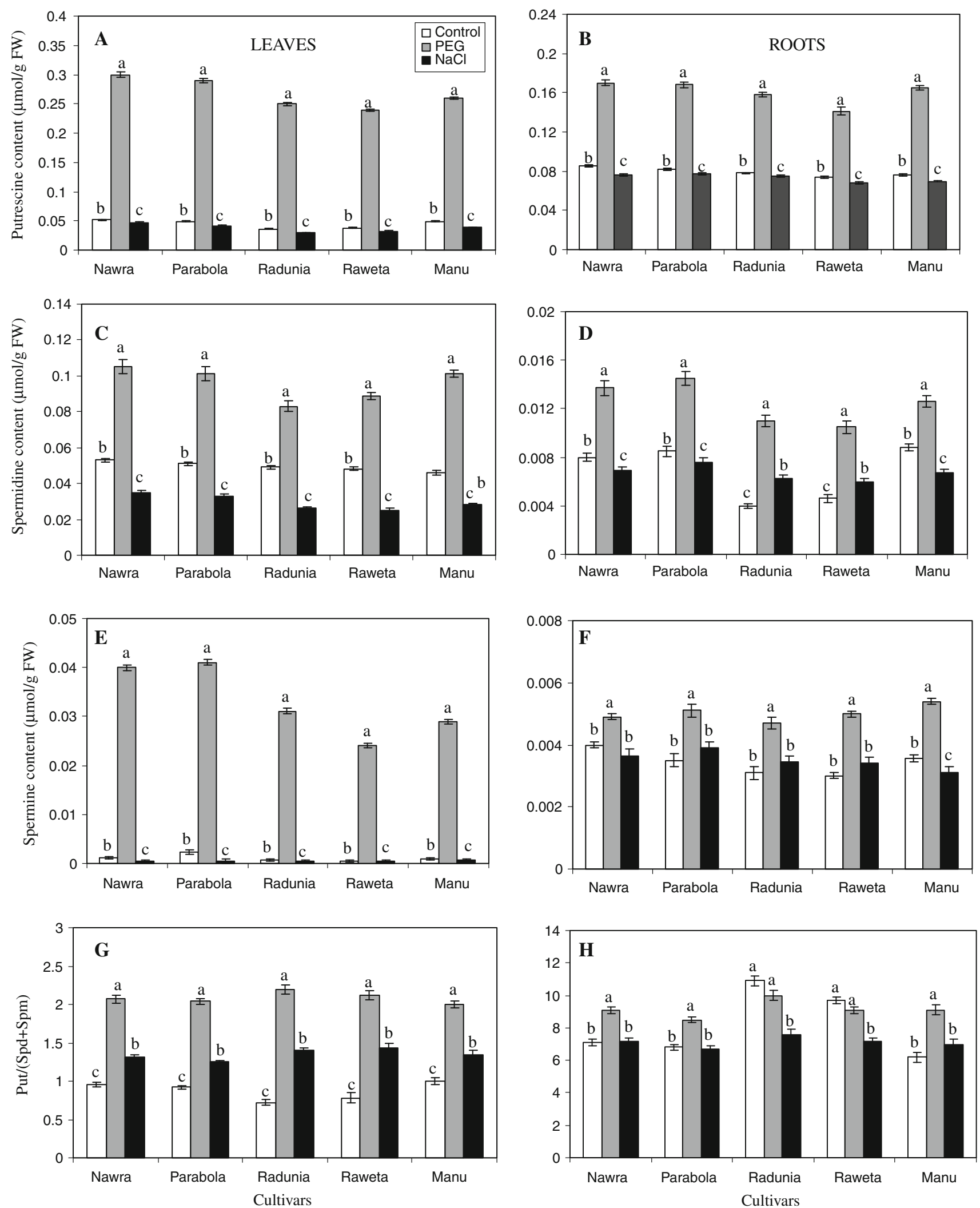

Fig. 3 Polyamine (putrescine-Put, spermidine-Spd and spermine-Spm concentrations and the ratio of $\mathrm{Put} /(\mathrm{Spd}+\mathrm{Spm})$ in the leaves $(\mathbf{a}, \mathbf{c}, \mathbf{e}, \mathbf{g})$ and roots $(\mathbf{b}, \mathbf{d}, \mathbf{f}, \mathbf{h})$ of 5 wheat varieties after culture on Hoagland (1:1 with water) media (control) and on the

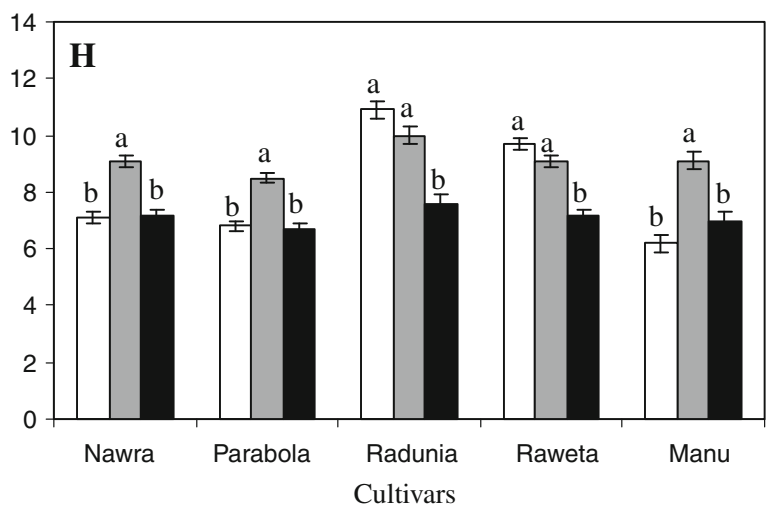

media supplemented with polyethylene glycol (PEG 6000, $\Psi=$ $-1.5 \mathrm{MPa})$ and $\mathrm{NaCl}(\Psi=-1.5 \mathrm{MPa})$ for 2 days. Values are mean $\pm \operatorname{SE}(n=6)$. Different letters indicate significant $(p<0.05)$ differences between treatments 
Table 3 Conjugated polyamine contends and ethylene level in the wheat leaves and roots of 5 varieties after a culture on Hoagland (1:1 with water) media (control) and on the media supplemented with polyethylene glycol (PEG 6000, $\Psi=-1.5 \mathrm{MPa})$ and $\mathrm{NaCl}(\Psi=$ $-1.5 \mathrm{MPa}$ ) for 2 days

\begin{tabular}{|c|c|c|c|c|c|c|c|}
\hline \multirow[t]{2}{*}{ Object } & \multirow[t]{2}{*}{ Treatment } & \multicolumn{2}{|c|}{ Cojugated putrescine $(\mu \mathrm{g} / \mathrm{g} \mathrm{FW})$} & \multicolumn{2}{|c|}{ Conjugated spermidine ( $\mu \mathrm{g} / \mathrm{g} \mathrm{FW})$} & \multicolumn{2}{|c|}{ Ethylene $\left(\mathrm{nl} \mathrm{g}^{-1} \mathrm{~h}^{-1}\right)$} \\
\hline & & Leaves & Roots & Leaves & Roots & Leavess & Roots \\
\hline \multirow[t]{3}{*}{ Nawra } & Control & $1.870 \pm 0.009^{\mathrm{a}}$ & $1.295 \pm 0.013^{\mathrm{a}}$ & $2.429 \pm 0.019^{\mathrm{b}}$ & $2.087 \pm 0.013^{\mathrm{b}}$ & $2.42 \pm 0.09^{\mathrm{a}}$ & $1.99 \pm 0.07^{\mathrm{b}}$ \\
\hline & PEG & $0.240 \pm 0.002^{\mathrm{c}}$ & $0.176 \pm 0.007^{\mathrm{c}}$ & $3.194 \pm 0.011^{\mathrm{a}}$ & $2.595 \pm 0.020^{\mathrm{a}}$ & $1.97 \pm 0.07^{\mathrm{b}}$ & $1.78 \pm 0.05^{\mathrm{c}}$ \\
\hline & $\mathrm{NaCl}$ & $0.611 \pm 0.003^{\mathrm{b}}$ & $0.531 \pm 0.006^{\mathrm{b}}$ & $0.400 \pm 0.012^{\mathrm{c}}$ & $0.514 \pm 0.009^{c}$ & $2.63 \pm 0.09^{\mathrm{a}}$ & $2.15 \pm 0.06^{\mathrm{a}}$ \\
\hline \multirow[t]{3}{*}{ Parabola } & Control & $1.700 \pm 0.008^{\mathrm{a}}$ & $1.384 \pm 0.010^{\mathrm{a}}$ & $2.346 \pm 0.010^{\mathrm{b}}$ & $1.991 \pm 0.011^{\mathrm{b}}$ & $2.50 \pm 0.07^{\mathrm{a}}$ & $2.02 \pm 0.06^{\mathrm{b}}$ \\
\hline & PEG & $0.204 \pm 0.001^{\mathrm{c}}$ & $0.189 \pm 0.005^{\mathrm{c}}$ & $2.868 \pm 0.013^{\mathrm{a}}$ & $2.476 \pm 0.010^{\mathrm{a}}$ & $1.95 \pm 0.06^{\mathrm{b}}$ & $1.69 \pm 0.04^{\mathrm{c}}$ \\
\hline & $\mathrm{NaCl}$ & $0.518 \pm 0.002^{\mathrm{b}}$ & $0.395 \pm 0.009^{\mathrm{b}}$ & $0.469 \pm 0.011^{\mathrm{c}}$ & $0.502 \pm 0.008^{\mathrm{c}}$ & $2.71 \pm 0.08^{\mathrm{a}}$ & $2.27 \pm 0.08^{\mathrm{a}}$ \\
\hline \multirow[t]{3}{*}{ Radunia } & Control & $1.493 \pm 0.014$ & $1.077 \pm 0.008$ & $2.345 \pm 0.010^{\mathrm{a}}$ & $1.888 \pm 0.012^{\mathrm{a}}$ & $2.63 \pm 0.05^{\mathrm{b}}$ & $2.14 \pm 0.03^{\mathrm{b}}$ \\
\hline & PEG & $\operatorname{Tr}$ & $\operatorname{Tr}$ & $2.188 \pm 0.009^{b}$ & $1.743 \pm 0.013^{\mathrm{b}}$ & $2.02 \pm 0.05^{\mathrm{c}}$ & $1.91 \pm 0.07^{\mathrm{c}}$ \\
\hline & $\mathrm{NaCl}$ & $\operatorname{Tr}$ & $\operatorname{Tr}$ & $0.101 \pm 0.016^{\mathrm{c}}$ & $0.097 \pm 0.005^{\mathrm{c}}$ & $2.76 \pm 0.07^{\mathrm{a}}$ & $2.23 \pm 0.04^{\mathrm{a}}$ \\
\hline \multirow[t]{3}{*}{ Raweta } & Control & $1.571 \pm 0.010$ & $1.100 \pm 0.012$ & $2.396 \pm 0.01^{\mathrm{a}}$ & $1.905 \pm 0.009^{\mathrm{a}}$ & $2.70 \pm 0.08^{\mathrm{b}}$ & $2.12 \pm 0.06^{\mathrm{b}}$ \\
\hline & PEG & $\operatorname{Tr}$ & $\operatorname{Tr}$ & $2.199 \pm 0.010^{\mathrm{b}}$ & $1.694 \pm 0.008^{\mathrm{b}}$ & $2.09 \pm 0.07^{\mathrm{c}}$ & $1.86 \pm 0.05^{\mathrm{c}}$ \\
\hline & $\mathrm{NaCl}$ & $\operatorname{Tr}$ & $\operatorname{Tr}$ & $0.092 \pm 0.011^{\mathrm{c}}$ & $0.079 \pm 0.009^{c}$ & $2.85 \pm 0.09^{\mathrm{a}}$ & $2.27 \pm 0.08^{\mathrm{a}}$ \\
\hline \multirow[t]{3}{*}{ Manu } & Control & $1.689 \pm 0.015$ & $1.308 \pm 0.013$ & $2.688 \pm 0.009^{\mathrm{b}}$ & $2.052 \pm 0.014^{\mathrm{b}}$ & $2.48 \pm 0.06^{\mathrm{a}}$ & $1.98 \pm 0.05^{\mathrm{b}}$ \\
\hline & PEG & $\operatorname{Tr}$ & $\operatorname{Tr}$ & $2.995 \pm 0.008^{\mathrm{a}}$ & $2.433 \pm 0.010^{\mathrm{a}}$ & $2.03 \pm 0.09^{\mathrm{b}}$ & $1.63 \pm 0.07^{\mathrm{c}}$ \\
\hline & $\mathrm{NaCl}$ & $\operatorname{Tr}$ & $\operatorname{Tr}$ & $0.320 \pm 0.005^{\mathrm{c}}$ & $0.401 \pm 0.007^{\mathrm{c}}$ & $2.57 \pm 0.09^{\mathrm{a}}$ & $2.10 \pm 0.08^{\mathrm{a}}$ \\
\hline
\end{tabular}

Values are mean $\pm \operatorname{SE}(n=6)$. Different letters indicate significant $(p<0.05)$ differences between treatments

control) and decreased further in the roots of Radunia and Raweta (more than 2 times). In $\mathrm{NaCl}$-stressed seedlings, POD activities increased in both leaves and roots, especially in Raweta and Radunia (Fig. 4c, d). CAT activities increased in leaves of all plants after PEG-treatment and decreased a little after $\mathrm{NaCl}$-treatment (Fig. 4e). Both osmotic stress factors stimulated a rise of CAT activity in roots and this effect was larger in Radunia and Raweta [about fivefold for PEG and fourfold for NaCl-stress; Fig. 4f)]. GR activity increased in both leaves (Fig. 4g) and roots (Fig. 4h) after application of both stresses. However, the largest changes were observed for PEG-treated Raweta and Radunia genotypes.

The level of ethylene emission was higher in the leaves than in the root systems (Table 3). After PEG-treatment ethylene production generally decreased while after $\mathrm{NaCl}$ treatment it increased in comparison to the control plants. The smallest changes were detected for Raweta and Radunia genotypes.

\section{Discussion}

From leaf water relations (Fig. 1) and from earlier studies (Filek et al. 2012) we concluded that PEG-treatment stimulated the osmotic stress to the higher degree than $\mathrm{NaCl}$, in spite of the same water potential application ( $\Psi=-1.5 \mathrm{MPa}$ ). The smaller effect of $\mathrm{NaCl}$ on LRWC and RDIR, in comparison with PEG, was probably due to a certain amount of osmotic adjustment caused by the presence of $\mathrm{Na}+$ and $\mathrm{Cl}-$ ions. Accumulation of these ions, in the initial phase of stress action, can affect (stimulate/ inhibit) the synthesis of other osmoprotectors (such as proline and/or carbohydrates) (de Lacerda et al. 2003).

Taking into account that proline acts as an osmo-regulator, osmo-protector or a regulator of redox potential of cells its concentration in many plants or tissues exposed to a variety of abiotic stresses has been frequently studied (Hare and Cress 1997; Mohammadkhani and Heidari 2008). The increase in the proline level, caused by osmotic stresses applied in the present experiment, confirmed observations known from the literature which showed that proline accumulation is the first response of plants exposed to osmotic stress. The accumulation of proline brought about by stress is a result of the reciprocal effects of two pathways - the increased expression of proline synthesizing enzymes (P5CS, P5CR and OAT) and repressed proline degradation enzyme (PDH) (Lin et al. 2002). The results of the current experiments showed that an increase in the proline content in both leaves and roots in Nawra and Parabola genotypes (selected as more tolerant) was higher than in Radunia and Raweta (selected as more sensitive) after both PEG and NaCl-treatments, in spite of greater values of proline registered in the control plants of the sensitive genotypes (Table 1). This indicates that not the initial level of this substance, but the activation of enzymes involved in its synthesis, is a key mechanism for a final concentration of proline. Moreover, the higher values of 

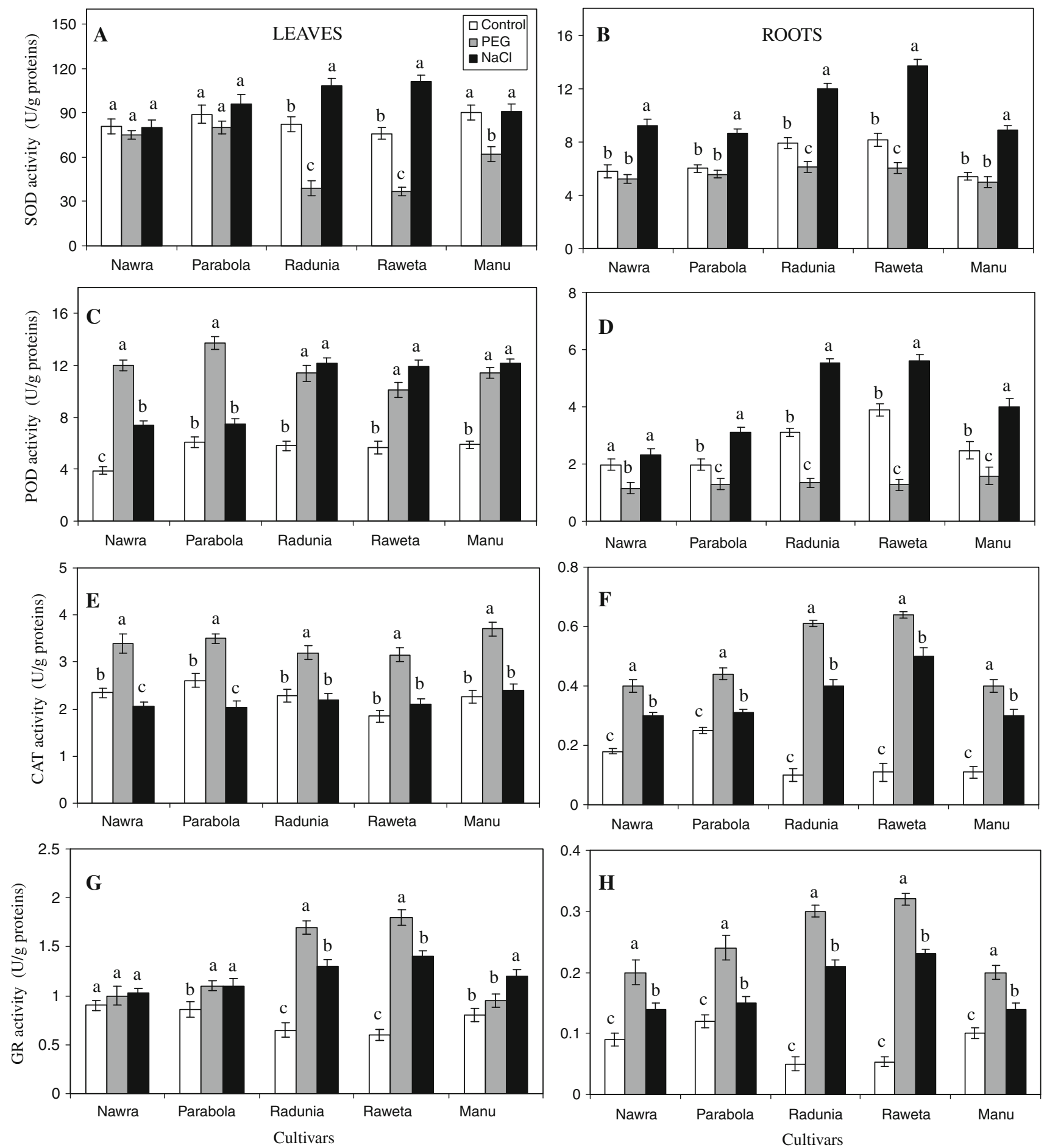

Fig. 4 Antioxidant activities (superoxide dismutase SOD, peroxidase POD, catalase CAT, glutathione reductase GR) levels in the leaves (a, $\mathbf{c}, \mathbf{e}, \mathbf{g})$ and roots $(\mathbf{b}, \mathbf{d}, \mathbf{f}, \mathbf{h})$ of 5 wheat varieties after culture on Hoagland (1:1 with water) media (control) and on the media

proline content measured for PEG-treated plants than $\mathrm{NaCl}$-treated plants, may be related to a higher mobilization of this metabolite synthesis in the case of a stronger stressor action. The data suggest that for proline supplemented with polyethylene glycol (PEG 6000, $\Psi=-1.5$ $\mathrm{MPa})$ and $\mathrm{NaCl}(\Psi=-1.5 \mathrm{MPa})$ for 2 days. Values are mean $\pm \mathrm{SE}$ $(n=6)$. Different letters indicate significant $(p<0.05)$ differences between treatments

accumulation wheat seedlings may evolve a mechanism coordinating the synthesis and inhibition of activities of different pathways. Proline can be synthesized using either glutamate or ornithine precursors by P5CS or OAT 
enzymes, respectively. Under many stresses, especially drought and salinity, P5CS was postulated as a critical enzyme in proline biosynthesis (Parida et al. 2008). The rise in P5CS activity, especially high after PEG-treatment, and in leaves of tolerant plants, together with no change in OAT activity (Fig. 2), indicated that the glutamate pathway may contribute to proline accumulation under this stress condition. In NaCl-treated plants, the increase in both P5CS and OAT activities suggested that the ornithine pathway could also be involved in proline synthesis in such stressed plants. In the sensitive genotypes exposed to both stressors, smaller changes in activities of these enzymes, together with a relatively weaker P5CR activity, i.e. enzyme involved in the last step of proline biosynthesis, may be responsible for the lower content of this metabolite as compared to the more resistant genotypes. In roots, lower P5CS activity compared to the leaves could limit the final proline content. However, the main pathway of the synthesis of this osmoprotectors seems to be more dependent on the stress factor (PEG or $\mathrm{NaCl}$ ) than on the plant tolerance to stress. Changes in the proline accumulation in leaves and roots of Manu plants exposed to both osmotic stresses were close to those observed for Nawra and Parabola. This suggests that the Finnish genotype was more tolerant to both PEG and NaCl-treatments.

Usually, the magnitude of proline accumulation is connected with the levels of carbohydrates (Mohammadkhani and Heidari 2008). The results of the present experiments showed that the changes in soluble sugars levels (Tables 1, 2) can also be associated with the proline content in leaves and roots of all investigated cultivars after the application of both stress factors. However, the correlation was significant only under PEG treatment $(r=0.9351$ and $r=0.7804$, for leaves and roots, respectively, $p<0.05$ ). The changes in total carbohydrates content were higher in the genotypes selected as tolerant which was consistent with the data of other authors (Prado et al. 2000). In less tolerant wheat cultivars, the lower sugar content measured under PEG-water stress, was probably caused by the weaker stimulation of their synthesis, similar to proline. In these cultivars, only saccharose synthesis seems to be activated. Probably, the lower content of osmoprotectors was responsible for the poorer resistance of the sensitive cultivars. As compared with PEG-treatment, NaCl-stress induced only minor changes in the sugars content of all investigated plants (Tables 1,2). We concluded that in these conditions, $\mathrm{Na}^{+}$and $\mathrm{Cl}^{-}$ions delivery and proline accumulation were sufficient to achieve the osmotic adjustment. Thus, the increase in the sugar content may be stimulated mainly during the operation of a stronger stress (PEG), and as a defense mechanism in tolerant cultivars.

The action of stress-induced PAs is often considered as similar to that of proline and other osmolytes (Kuznetzov and Shevyakova 2007). The relationship between increased levels of proline and PAs was supported by the finding of the common blocker difluoromethylarginine, which inhibits the synthesis of Put and accumulation of proline under both control and stress conditions (Bouchereau et al. 1999). In our study, high correlation coefficients between the content of proline and total PAs obtained for plants grown under stress conditions induced by PEG ( $r=0.9921$ and $r=0.9634$, for leaves and roots, respectively, $p<0.05$ ), and under NaCl-treatment $(r=0.6712$ and $r=0.6987$, for leaves and roots, respectively, $p<0.05$ ), indicate that PAs may function as an additional organic osmoprotector under osmotic stresses. As the polyvalent cations, PAs can enhance cell osmotic conditions, as well as inorganic ions $\left(\mathrm{Na}^{+}, \mathrm{Cl}^{-}\right)$. The lower correlation coefficients, calculated for $\mathrm{NaCl}$ than for PEG-treated plants, suggest that smaller amounts of PA cations are necessary for osmotic stabilization in the inorganic ions presence, under $\mathrm{NaCl}$ stress conditions, and the additional PAs synthesis was not necessary.

The correlations between PAs and sugars content were obtained only for PEG-stressed plants $(r=0.9585$ and $r=0.7688$, for leaves and roots, respectively, $p<0.05$ ), similarly as for carbohydrate-proline relationships. This suggests that PAs, like sugars may be involved in cell protection mainly against the action of a strong stress, induced after PEG-application.

In osmotic stress conditions, the rise in PAs was higher in wheat genotypes selected as more tolerant and was in agreement with findings of other authors, suggesting the special role of Spd and Spm synthesis under water deficit in plants (Liu et al. 2004a). However, our results also indicated that free-Put can be involved in the promotion of wheat plants tolerance to both PEG and $\mathrm{NaCl}$-stresses. This conclusion was supported by the calculations which indicated the increase in the ratio Put/(Spd $+\mathrm{Spm})$ in leaves of all studied genotypes (Fig. 3g). Smaller changes in this ratio relative to the control, observed in the more tolerant cultivars, suggest that the synthesis of Spm and Spd was more effective in the tolerant genotypes. In roots, similar to the other organic osmoprotectors, the slighter changes in PAs content, in comparison with leaves, may be connected with smaller tolerance of these organs to both stresses. The involvement of Put in the protection of roots was characterized only in the tolerant cultivars and only under PEG stress (Put/(Spd + Spm) ratio; Fig. 3h). After $\mathrm{NaCl}$ application, the increase in Spd synthesis in stress-sensitive genotypes was responsible for the decrease of Put/ $(\mathrm{Spd}+\mathrm{Spm})$ ratio.

Liu et al. (2004a) demonstrated that in leaves of wheat seedlings, the conversion of free-PAs to PAs-conjugates and formation of protein-glutathione-PAs and proteinglutathione-PAs-protein complexes could play an 
important role in the post-transcriptional modifications of proteins and could stabilize the conformation and function of proteins under PEG-osmotic stress. From our results one can conclude that, under PEG-treatment, only the conjugated Spd was involved in the protection of tolerant wheat seedlings in both leaves and roots. The stabilization of proteins by Spd-conjugates may serve as an additional defense mechanism in strong stress conditions, generated after PEG application.

The negative correlation between total PAs content and ethylene, in PEG-treated plants $(r=-0.9076$ and $r=$ -0.5740 for leaves and roots respectively, $p<0.05$ ), was calculated. This correlation represents a feedback of the inhibition of the enzyme action in one pathway and of enzyme activation in the other pathway (Pandey et al. 2000). Ethylene inhibited the activities of arginine decarboxylase and SAM decarboxylase thus reducing PAs contents (Bouchereau et al. 1999). However, other results showed that PAs inhibited the accumulation of transcript of 1-aminicyclopropane-1-carboxylic acid (precursor of ethylene) synthase (Garnica et al. 2009). The correlations observed in our study suggested that in the investigated wheat genotypes, the increase in PA concentration inhibited ethylene synthesis in PEG-treated plants (Table 3). Contrary, NaCl-treatment which caused the increase in ethylene synthesis could, in turn, influence a decrease in free PAs metabolism and also their conversion to conjugated forms. Correlation coefficients between PAs and ethylene were not significant in $\mathrm{NaCl}$-stressed plants and suggest that the predominant effect was synthesis of ethylene (as a signal molecule), in those conditions.

Changes in activities of the antioxidant enzymes SOD, POD, CAT and GR observed in the tolerant and sensitive genotypes were related to the mobilization of the protective system in stress conditions caused by ROS (Xu et al. 2011). Correlation coefficients calculated for SOD, the enzyme engaged as the first in the defense mechanism against oxygen radicals (Alscher et al. 2002) and other enzymes revealed significant increases in the leaves of PEG-treated plants $(r=0.6965,0.8365$ and -0.8950 for CAT, POD and GR, respectively, $p<0.05$ ). For roots, the correlation was shown only in the case of CAT and GR $(r=0.9407$ and 0.9625 , respectively, $p<0.05$ ). This can indicate a less effective mobilization of antioxidant enzymes in roots than in leaves, under strong osmotic stress, as it was shown earlier for non-enzymatic osmoprotectors. Under $\mathrm{NaCl}$ treatment, which induced a smaller osmotic stress, the correlations between SOD and all other enzymes were significant $(r=0.9803,0.8637$ and 0.9792 for CAT, POD and GR respectively, $p<0.05$ ) in the case of the roots, whilst for the leaves, the correlations were significant only for POD and GR ( $r=0.6501$ and 0.9116 , respectively, $p<0.05$ ). Therefore, the mobilization of antioxidant enzymes in the roots may be a sufficient defense under $\mathrm{NaCl}$ stress conditions, and thus it did not require such significant amounts of other osmoprotectors.

In conclusion, in spite of the same water pressure $(-1.5 \mathrm{MPa})$ initiated by $\mathrm{PEG}$ and $\mathrm{NaCl}$ in the growth medium, PEG-treatment stimulated to a higher degree than $\mathrm{NaCl}$, osmotic stress in plants. The mobilization of a protective mechanism in the case of PEG-stressed plants was generated by an increase in activities of enzymes responsible for the syntheses of non-enzymatic (proline, from glutamate as a precursor, and carbothydrates) and enzymatic osmoprotectants as well as free-PAs and conjugatedSpd. Under $\mathrm{NaCl}$ conditions, ion $\left(\mathrm{Na}^{+}\right.$and $\left.\mathrm{Cl}^{-}\right)$accumulation may be used as an inorganic osmoprotectant in cells. Therefore, the organic osmoprotectants may be formed in smaller amounts, including the synthesis of proline (from both glutamate and ornithine) and saccharose only. Moreover, the stimulation of the ethylene pathway instead of PAs was initiated. However, similar to PEG-induced stress, $\mathrm{NaCl}$-treatment activated the antioxidative enzyme protective system.

Acknowledgments This work was partly supported by Grant No. 556/NCOST/2009/0.

Open Access This article is distributed under the terms of the Creative Commons Attribution License which permits any use, distribution, and reproduction in any medium, provided the original author(s) and the source are credited.

\section{References}

Aebi H (1984) Catalase in vitro. Methods Enzymol 105:121-126

Alscher RG, Erturk N, Heath LS (2002) Role of superoxide dismutases (SODs) in controlling oxidative stress in plants. J Exp Bot 53:1331-1341

Bates LS, Waldren RP, Teare ID (1973) Rapid determination of free proline for water-stress studies. Plant Soil 39:205-207

Bouchereau A, Aziz A, Larher F, Martin-Tanguy J (1999) Polyamines and environmental challenges: recent development. Plant Sci 140:103-125

Bradford MMA (1976) A rapid and sensitive method for the quantitation of microgram quantities of protein utilizing the principle of protein-dye binding. Anal Biochem 72:248-254

Cvikrová M, Binarová P, Cenklová V, Eder J, Macháčková I (1999) Reinitiation of cell division and polyamine and aromatic monoamine levels in alfalfa explants during the induction of somatic embryogenesis. Physiol Plant 105:330-337

de Lacerda CF, Cambraia J, Oliva MA, Ruiz HA, Prisco JT (2003) Solute accumulation and distribution during shoot and leaf development in two sorghum genotypes under salt stress. Environ Exp Bot 49:107-120

Filek M, Biesaga-Kościelniak J, Marcińska I, Cvikrová M, Macháčková I, Krekule J (2010) Contents of polyamines during vernalization in wheat and the effect of zearalenone. Biol Plant 54:483-487

Filek M, Walas S, Mrowiec H, Rudolphy-Skórska E, Sieprawska A, Biesaga-Kościelniak J (2012) Membrane permeability and 
micro- and macro-element accumulation in spring wheat cultivars Turing the short-term effect of salinity- and PEG-induced water stress. Acta Physiol Plant 34:985-995

Foyer CH, Halliwell B (1976) The presence of glutathione and glutathione reductase in chloroplasts: proposed role in ascorbic acid metabolism. Planta 133:21-25

Garnica M, Houdusse F, Yvin JC, Garcia-Mina JM (2009) Nitrate supply induced changes in polyamine content and ethylene production in wheat plants grown with ammonium. J Plant Physiol 166:363-374

Goyal M, Asthir B (2010) Polyamine catabolism influences antioxidative defense mechanism in shoots and roots of five wheat genotypes under high temperature stress. Plant Growth Regul 60:13-25

Hare PD, Cress WA (1997) Metabolic implications of stress-induced proline accumulation in plants. Plant Growth Regul 21:79-102

Iqbal M, Ashraf M, Jamil A, Rehman S (2006) Does seed priming induce changes in the levels of some endogenous plant hormones in hexaploid wheat plants under salt stress? J Int Plant Biol 48:181-189

Ke DS, Wang AG, Sun GC, Dong LF (2002) The effect of active oxygen on the activity of ACC synthase induced by exogenous IAA. Acta Bot Sinica 44:551-556

Kovács Z, Simon-Sarkadi L, Szűcs A, Kocsy G (2010) Different effects of cold, osmotic stress and abscisic acid on polyamine accumulation in wheat. Amino Acids 38:623-631

Kubiś J (2008) Exogenous spermidine differently alters activities of some scavenging system enzymes, $\mathrm{H}_{2} \mathrm{O}_{2}$ and superoxide radical levels in water-stressed cucumber leaves. J Plant Physiol 165:397-406

Kuznetzov VV, Shevyakova NI (2007) Polyamines and stress tolerance of plants. Plant Stress 1:50-71

Li C, Wang G (2004) Interaction between reactive oxygen species, ethylene and polyamines in leaves of Glycyrrhiza inflate seedlings under root osmotic stress. Plant Growth Regul 45:55-60

Lin CC, Hsu YT, Kao CH (2002) The effect of $\mathrm{NaCl}$ on proline accumulation in rice leaves. Plant Growth Regul 36:275-285

Liu HP, Dong BH, Zhang YY, Liu ZP, Liu YL (2004a) Relationship between osmotic stress and the level of free, conjugated and bound polyamines in leaves of wheat seedlings. Plant Sci 166:1261-1267

Liu HP, Liu J, Zhang Y, Liu YL (2004b) Relationship between ATPase activity and conjugated polyamines in mitochondrial membrane from wheat seedling roots under osmotic stress. J Environ Sci 16:712-716

Liu HP, Zhy ZX, Liu TX, Li CH (2006) Effects of osmotic stress on the kinds, forms and levels of polyamines in wheat coleoptiles. J Plant Physiol Mol Biol 32:293-299

Liu J-H, Inoue H, Moriguchi T (2008) Salt stress-mediated changes in free polyamine titers and expression of genes responsible for polyamine biosynthesis of apple in vitro shoots. Environ Exp Bot 62:28-35

Lück H (1965) Peroxidase in methods of enzymatic analysis. In: Bergemeyer HU (ed) Methods of enzymic analysis. Academic Press, New York, p 895

Lutts S, Majerus V, Kinet JM (1999) $\mathrm{NaCl}$ effects on proline metabolism in rice (Oryza sativa) seedlings. Physiol Plant 105:450-458

Madan S, Nainawatee HS, Jain RH, Chowdhury JB (1995) Proline and proline metabolizing enzymes in in vitro selected $\mathrm{NaCl}-$ tolerant Brassica juncea L. under salt stress. Ann Bot 76:51-57
McCord JM, Fridovich I (1969) Superoxide dismutase: an enzymatic function for erythrocuprein (hemocuprein). J Biol Chem 244:6049-6055

Mohammadkhani N, Heidari R (2008) Drought-induced accumulation of soluble sugars and proline in two maize varieties. World Appl Sci J 3:448-453

Mól R, Filek M, Machačkova I, Matthys-Rochon E (2004) Ethylene synthesis and auxin augmentation in pistil tissues are important for egg cell differentiation after pollination in maize. Plant Cell Physiol 45:1396-1405

Nagy Z, Galiba G (1995) Drought and salt tolerance are not necessarily linked: a study on wheat varieties differing in drought resistance under consecutive water salinity stresses. J Plant Physiol 145:168-174

Pandey S, Ranade SA, Nagar PK, Kumar N (2000) Role PAs and ethylene as modulator of plant senescence. J Biol Sci 25:291-299

Parida AK, Dagaonkar VS, Phalak MS, Aurangabadkar LP (2008) Differential responses of the enzymes involved in proline biosynthesis and degradation in drought tolerant and sensitive cotton genotypes during drought stress and recovery. Acta Physiol Plant 30:619-627

Prado FE, Boero C, Gallarodo M, Gonzalez JA (2000) Effect of $\mathrm{NaCl}$ on germination, growth and soluble sugar content in Chenopodium quinoa wild seeds. Bot Bull Acad Sin 41:27-34

Scaramagli S, Biondi S, Leone A, Grub S, Torrigiani P (2000) Acclimation to low-water potential in potato cell suspension cultures leads to changes in putrescine metabolism. Plant Physiol Biochem 38:345-351

Slocum RD, Flores HE, Galson AW, Weinstein LH (1989) Improved method for HPLC analysis of polyamines, agmatine and aromatic monoamines in plant tissue. Plant Physiol 89:512-517

Stines AP, Naylor DJ, Hoj PB, Heeswijck RV (1999) Proline accumulation in developing grapevine fruit occurs independently of changes in the level of pyrrolline-5-carboxylate synthetase mRNA or protein. Plant Physiol 120:923-931

Sucre B, Suárez N (2011) Effect of salinity and PEG-induced water stress on water status, gas exchange, solute accumulation, and leaf growth in Ipomoea pescaprae. Environ Exp Bot 70:192-203

Tang W, Newton RJ (2005) Polyamines reduce salt-induced oxidative damage by increasing the activities of antioxidant enzymes and decreasing lipid peroxidation in Virginia pine. Plant Growth Regul 46:31-43

Tiburcio AF, Altabella T, Borrell T, Masgrau C (1997) Polyamines metabolism and its regulation. Physiol Plant 100:664-674

Valentovic P, Luxova M, Kolarovic L, Gasparicova O (2006) Effect of osmotic stress on compatible solutes content, membrane stability and water relations in two maize cultivars. Plant Cell Environ 52:186-191

Van Huylenbroeck JM, Debergh PC (1996) Impact of sugar concentration on photosynthesis and carbon metabolism during ex vitro acclimatisation of Statyphyllum plantlets. Physiol Plant 96:298-304

Vogel RH, Kopac MJ (1960) Some properties of ornithine- $\gamma$ transaminase from neurospora. Biochem Biophys Acta 37:539-540

Xu S, Hu J, Li Y, Ma W, Zheng Y, Zhu S (2011) Chilling tolerance in Nicotiana tabacum induced by seed priming with putrescine. Plant Growth Regul 63:279-290 